\title{
DAMAGE ASSESSMENT CAUSED BY RODENTS TO SOME FIELD CROPS IN UPPER EGYPT.
}

Metwaly, A.M. ${ }^{1}$; K.H. Abdel-Gawad ${ }^{2}$; M.A. Ahmed ${ }^{1}$ and H.S.K. Ahmed ${ }^{1}$

1- Agric. Zoology and Nematology Depart., Fac.of Agric., AL-Azher Univ., Egypt.

2- Agric. Zoology, plant protection Depart., Fac.of Agric., Assiut Univ., Egypt.

ABSTRACT

The present study was carried out in fields located in al-Azhar University farm in Assiut district to determine the damage in broad bean, wheat, maize and sorghum which caused by the rodent species and the time during which damage reaches its maximum. Samples were taken at five distances from the outer field border (1.0, 10.0, 20.0, 30.0 and 40.0 meters).

The results showed that rodents attack broad bean plants from $15^{\text {th }}$ January to $20^{\text {th }}$ March. The highest attack by rodents was recorded during the period of the pod filling stage. The lowest damage recorded during the period from 15 to $30^{\text {th }}$ January. The damage was concentrated in the broad bean plants adjacent to the field border, then decreased progressively towards the middle of the field. The lowest attack was presented in plants situated at 40 meters from the field border. Rodent attack the wheat plants from $1^{\text {st }}$ April to $20^{\text {th }}$ May and the maximum attack was recorded during the period in the doughy stage. During the period from $1^{\text {st }}$ to $8^{\text {th }}$ April through the milky stage the lowest damage in wheat plants was recorded. Damage decreased gradually towards the center of the field. The highest destruction was recorded at the field border followed by the ten meters beside the field border. The lowest damage was registered at 40 meters apart from field borders. Rodents attack maize plants from the period of $15^{\text {th }}$ September till $20^{\text {th }}$ October and the maximum attack was observed during the period from $13^{\text {th }}$ September to $20^{\text {th }}$ October. The greatest damage was concentrated in the plants near to the field border and in the first ten meters beside the field borders and lowest damage was presented in the distance more than 10 meters far away from field borders. Rodents attack the sorghum plants from $15^{\text {th }}$ September to $21^{\text {st }}$ October. The highest damage was clear in the plants near of the field borders and with increasing distances. The damage was gradually tended to reduce. The minimum rodent of damage was presented in plants situated at 20-30 meters from the field border.

\section{INTRODUCTION}

In Egypt, rodents problem increased in the last two decades. The main reasons are due to the diversion in agriculture system, land reclamation and construction of new cities in the desert areas and the wide usage of pesticides for controlling agricultural pastes that leads to kill the natural enemies of rodents such as reptiles and wild birds. In El-Minia Governorate, Asran (1991) found that the damage cased by A. niloticus in wheat and maize crop started at the early growth stage and increased during the milky and dough growth stages. Asran et al., (1991) found that the damage caused by rats in wheat field increased from $0.47 \%$ in December to $2.83 \%$ in April. In Fayoum Governorate, Abdel-Hamid (1997) found that wheat and maize 
crops were attacked heavily by $R$. rattus during the milky and dough stages. Embarak (1997) estimated the damage caused by rodents in three field crops (maize, wheat and barley). He found that the rodent damage concentrated at five meters beside the borders of damaged maize ears, wheat and barley. The percentages of damage were 11.67, 4.5 and $3.5 \%$ for maize, wheat and barley, respectively.

El-Nashar (1998) estimated the damage caused by rodents in wheat and maize fields at Mallawy district, El-Minia Governorate through two successive years (1995 and 1996). He found that the wheat crop was attacked heavily by $M$. musculus, $A$. niloticus and $R$. rattus during the milky and dough stages. Also, he found that, the losses were very low at the early stage of maize crop, than increased gradually to reach up to their maximum at the ripening stages. Abdel-Gawad et al., (2000) studied the damage caused by rodent to both lodging and standing maize plant, and the infestation was much higher at the border of the field and decreased towards the field center. The damage in lodging plants was comparatively high as compared with standing ones. It was recorded till $30 \mathrm{~m}$. from the border. The damage included the ear and grain weight and decreased the final yield. Ahmed (2001) estimated the damage caused by A. niloticus in wheat and maize fields in Sohag governorate. He found that wheat crop was heavily attacked during milky and dough stages.

The current study was carried out to assess the damage caused by rodents to some field crops (wheat, broad been, maize and sorghum) at different growth stages.

\section{MATERIALS AND METHODS}

The current study was carried out at Al-Azhar University Experimental Farm in Assiut Governorate, Egypt. The chosen area represents hundreds feddan cultivated with different field crops, vegetables and fruit trees as well as some sheep farms. There are many of irrigation \& drainage canals buildings and woodland areas. This work was initiated to estimate the damage caused by rodents and defined the damage peak period in winter crops (wheat and broad been) and summer crops (sorghum and maize). An area of two feddans for each field crop was selected. Twenty five samples were taken from each field by using quadrate wooden frame $(100 \times 100 \mathrm{~cm})$ with five replicates for each level. Samples were taken through five distances from the outer border of the field, i.e., 1, 10, 20, 30 and 40 meters.

The attacked plants were estimated as average number of broad bean and wheat. While in case of maize and sorghum the attacked plants were estimated as average percentage from the total examined plants in each distance. The numbers of damaged and undamaged plants inside the frame for every single sample were counted. From the maturity stage till the harvest the average infestation of the plant and the loss of the grains in ears, pods and awns were estimated in each area as percent of infested plants from the total examined plants. The species of rodent prevailed in the field study were trapped and identified. 


\section{RESULTS AND DISCUSSIONS}

\section{Broad beans (Vicia faba)}

The average number of infested pods $/ \mathrm{m}^{2}$ of broad bean by rodents at different sampling dates and distances during 2004 and 2005 seasons are given in Table 1. The obtained data revealed that rodents started to attack broad bean plants on January 15 till the harvesting time (19 March). The mean number of infested pods $/ \mathrm{m}^{2}$ ranged from 0.32 to 13.76 and from 0.28 to 16.42 in the season of 2004 and 2005 , respectively. In both seasons, the period of $5-27^{\text {th }}$ February was the most preferred time for rodents to infest the pods that were in the pot filling stage. In the last examination dates in both seasons, no more infested pods were recorded because of the hardness of the grains. The lowest damage and the lowest number of infested pods $/ \mathrm{m}^{2}$ of broad bean were recorded during the period of $15-30^{\text {th }}$ January in both seasons. The attack was more obvious and concentrated in plants adjacent to the field border and then decreased progressively towards the middle of the field. These findings were in agreement with those obtained by Embarak (1997). The maximum number of infested pods $/ \mathrm{m}^{2}$ of broad bean by rodents (13.38 and 14.54 pods $/ \mathrm{m}^{2}$ in both seasons) was concentrated in the plants near the border of the field. The minimum damage (3.64 and $5.88 \mathrm{pods} / \mathrm{m}^{2}$ in both seasons) was recorded on plants situated at 40 meters from field borders toward the center. In both seasons the damage caused by rodents occurred at distances 20 and 30 meters from field border did not significantly different. The results revealed that there was significant difference between the examination dates of damage caused by rodents.

\section{Wheat (Tritcum sp.)}

Data in Table 2 show average number of infested wheat plants $/ \mathrm{m}^{2}$ by rodents at different dates and distances during 2004 and 2005 seasons. The rodents attacked the wheat plants from $1^{\text {st }}$ April to the harvesting time (20 May) in both seasons. Average number of infested wheat plants $/ \mathrm{m}^{2}$ ranged from 2.16 to 14.28 and from 1.84 to 12.16 plants in the $1^{\text {st }}$ and $2^{\text {nd }}$ season, respectively. The highest number of infested plants $/ \mathrm{m}^{2}$ was recorded during the period from $22^{\text {nd }}$ April to $6^{\text {th }}$ May in both seasons. In this period the grains were in the doughy stage. Numbers of infested wheat plants $/ \mathrm{m}^{2}$ were 6.86 , 9.36, 12.9, and 13.84 in 2004 while they were $5.40,7.52,10.48$, and 11.84 in 2005 in samples taken at 22, 29 April, 6 and 13 May, respectively. The minimum values were detected during the period from $1^{\text {st }}$ to $8^{\text {th }}$ April. Also, the destruction declined to its minimum at the harvesting stage before the gathering time, in both seasons. These results reveal that controlling rodents under the field conditions must be start before $22^{\text {nd }}$ April after this time the rodent may be transferred from the field to the storages. Data show that the number of infested wheat plants $/ \mathrm{m}^{2}$ was gradually decreased by increasing the distances from 1.0 to 40 meters. In another words, the damage decreased gradually towards the center of the field. The highest destruction (14.10 and 11.82 plants $/ \mathrm{m}^{2}$ in both seasons) was recorded at the field border followed by the ten meters beside the border ( 8.98 and 6.98 plants $/ \mathrm{m}^{2}$ in both 
seasons). The lowest damage in wheat plants (4.33 and 4.63 plants $/ \mathrm{m}^{2}$ in both seasons) was recorded at 40 meters distances from the field border.

\section{Maize (Zea maize):}

The percentages of infested maize ears $/ \mathrm{m}^{2}$ by rodents at different dates and distances are shown in Table (3). The obtained data show that rodents attack maize plants once ears appearance to the harvesting. The maximum infestation was observed during the pre harvest stage. The maximum percentage of infested maize ears $/ \mathrm{m}^{2}\left(11.35\right.$ and 12.09 ears $\left./ \mathrm{m}^{2}\right)$ was recorded on the period from $13^{\text {th }}$ to $20^{\text {th }}$ October in both seasons. The damage decreased gradually by increasing the distances from the field border. The maximum percentage of infested maize ears $/ \mathrm{m}^{2}$ by rodents was concentrated in the plants near the field border. In the first season, the damage was 19.98 ears $/ \mathrm{m}^{2}$ at such distance $(1.0 \mathrm{~m})$. While, in the second season the maximum infestation (12.05 and 10.97 ears $\left./ \mathrm{m}^{2}\right)$ by rodents was concentrated in the plants adjacent the field border and in the first ten meters beside the field border. No differences among the three distances namely 20 , 30 and 40 meters regarding the damage caused by rodent in both seasons. One can say that, damage caused by rodents in maize field did not affect with distances more than 10 meters far away from field borders. The rodent species prevailed in field crops was $A$. niloticus. These results are in agreement with those obtained by Abazaid (1997) who found that the rodent species prevailed in maize was $A$. niloticus, and the damage caused by rodent was much higher in the field borders and decreased towards the field center. It may be due to the concentration of the rodent burrows beside the borders and the side of the irrigation canals. 
Metwaly, A.M. et al

Table (1): The average number of infested pods/ $\mathrm{m}^{2}$ of broad beans in relation to time and distances during the winter season of 2004 and 2005.

\begin{tabular}{|c|c|c|c|c|c|c|}
\hline \multirow{3}{*}{$\begin{array}{c}\text { Sampling } \\
\text { date }\end{array}$} & \multicolumn{5}{|c|}{ Average number of infested pods / $\mathrm{m}^{2}$ in 2004} & \multirow{3}{*}{$\begin{array}{c}\text { (2) Grand avg } \\
\text { Sampling } \\
\text { date }\end{array}$} \\
\hline & \multicolumn{5}{|c|}{ Distance (m) } & \\
\hline & $1.0 \mathrm{~m}$ & $10.0 \mathrm{~m}$ & $20.0 \mathrm{~m}$ & $30.0 \mathrm{~m}$ & $40.0 \mathrm{~m}$ & \\
\hline Jan. 15 & (1) 1.2 hij & $0.4 \mathrm{ij}$ & $0.0 \mathrm{j}$ & $0.0 \mathrm{j}$ & $0.0 \mathrm{j}$ & $0.32 \mathrm{E}$ \\
\hline 22 & 2.2 ghij & $0.8 \mathrm{hij}$ & $0.2 \mathrm{j}$ & $0.2 \mathrm{j}$ & $0.0 \mathrm{j}$ & $0.68 \mathrm{E}$ \\
\hline 29 & 4.4 efghij & $1.8 \mathrm{ghij}$ & $1.0 \mathrm{hij}$ & 0.8 hij & $0.6 \mathrm{ij}$ & $1.72 \mathrm{DE}$ \\
\hline Feb. 5 & 6.0 defgh & $2.8 \mathrm{fghij}$ & 2.0 ghij & 2.0 ghij & 2.0 ghij & $2.96 \mathrm{D}$ \\
\hline 12 & 9.8 bcdef & 5.4 defgh & 4.6 defghi & 4.0 efghij & 2.4 ghij & $5.24 \mathrm{C}$ \\
\hline 19 & $16.0 \mathrm{ab}$ & 10.6 bcde & 6.4 cdefg & 5.2 defgh & 3.4 fghij & $8.32 \mathrm{~B}$ \\
\hline 26 & $22.6 \mathrm{a}$ & $13.8 \mathrm{abc}$ & $11.0 \mathrm{bcd}$ & 8.6 bcdef & 7.0 cdefg & $12.60 \mathrm{~A}$ \\
\hline Mar. 5 & $23.6 \mathrm{a}$ & $15.6 \mathrm{ab}$ & $11.8 \mathrm{bcd}$ & $10.0 \mathrm{bcde}$ & 7.0 cdefg & $13.60 \mathrm{~A}$ \\
\hline 12 & $24.0 \mathrm{a}$ & $16.0 \mathrm{ab}$ & $11.8 \mathrm{bcd}$ & 10.0 bcde & $7.0 \mathrm{cdefg}$ & $13.76 \mathrm{~A}$ \\
\hline 19 & $24.0 \mathrm{a}$ & $16.0 \mathrm{ab}$ & $11.8 \mathrm{bcd}$ & 10.0 bcde & 7.0 cdefg & $13.76 \mathrm{~A}$ \\
\hline $\begin{array}{l}\text { (3) Grand avg. } \\
\text { distance }\end{array}$ & $13.38(\mathrm{~A})$ & $8.32(\mathrm{~B})$ & $6.06(\mathrm{C})$ & 5.08 (CD) & 3.64 (D) & \\
\hline \multicolumn{7}{|c|}{2005} \\
\hline Jan. 16 & (1) $1.0 \mathrm{j}-\mathrm{I}$ & $0.4 \mathrm{kl}$ & 0.01 & 0.01 & 0.01 & $0.28 \mathrm{E}$ \\
\hline 23 & $2.4 \mathrm{f}-\mathrm{I}$ & $1.8 \mathrm{~h}-\mathrm{I}$ & $0.4 \mathrm{k}-\mathrm{I}$ & $0.4 \mathrm{k}-\mathrm{I}$ & $0.4 \mathrm{k}-\mathrm{I}$ & $1.08 \mathrm{DE}$ \\
\hline 30 & $4.4 \mathrm{~d}-\mathrm{I}$ & $3.8 \mathrm{e}-\mathrm{I}$ & $1.6 \mathrm{i}-\mathrm{I}$ & $1.4 \mathrm{j}-\mathrm{I}$ & $1.4 \mathrm{j}-\mathrm{I}$ & $2.52 \mathrm{DE}$ \\
\hline Feb. 6 & $7.2 \mathrm{~b}-\mathrm{I}$ & $5.0 \mathrm{~d}-\mathrm{I}$ & $3.4 \mathrm{e}-\mathrm{I}$ & $3.4 \mathrm{e}-\mathrm{I}$ & $2.8 \mathrm{~g}-\mathrm{I}$ & $4.36 \mathrm{CD}$ \\
\hline 13 & $12.8 \mathrm{a}-\mathrm{h}$ & $10.0 \mathrm{a}-\mathrm{I}$ & $6.8 \mathrm{c}-\mathrm{I}$ & $7.0 \mathrm{c}-\mathrm{I}$ & $5.4 \mathrm{~d}-\mathrm{I}$ & $8.40 \mathrm{BC}$ \\
\hline 20 & $18.8 \mathrm{a}-\mathrm{c}$ & 16.2 a-e & $11.4 \mathrm{a}-\mathrm{k}$ & $10.4 \mathrm{a}-\mathrm{I}$ & $8.2 \mathrm{c}-\mathrm{I}$ & $13.00 \mathrm{AB}$ \\
\hline 27 & $22.4 \mathrm{ab}$ & 17.8 a-d & $14.0 \mathrm{a}-\mathrm{i}$ & $12.0 \mathrm{a}-\mathrm{k}$ & 9.6 b-I & $15.16 \mathrm{~A}$ \\
\hline Mar.6 & $25.2 \mathrm{a}$ & $19.0 \mathrm{a}-\mathrm{c}$ & $15.4 \mathrm{a}-\mathrm{g}$ & $13.6 \mathrm{a}-\mathrm{j}$ & $10.2 \mathrm{~b}-\mathrm{l}$ & $16.68 \mathrm{~A}$ \\
\hline 13 & $25.6 \mathrm{a}$ & 19.4 a-c & $15.6 \mathrm{a}-\mathrm{f}$ & $13.6 \mathrm{a-j}$ & $10.4 \mathrm{~b}-\mathrm{I}$ & $16.92 \mathrm{~A}$ \\
\hline 20 & $25.6 \mathrm{a}$ & 19.4 a-c & 15.6 a-f & $13.6 \mathrm{a-j}$ & $10.4 \mathrm{~b}-\mathrm{I}$ & $16.92 \mathrm{~A}$ \\
\hline $\begin{array}{l}\text { (3) Grand avg. } \\
\text { distance }\end{array}$ & $14.54(\mathrm{~A})$ & $11.28(\mathrm{AB})$ & $8.42(\mathrm{BC})$ & 7.54 (C) & $5.88(\mathrm{C})$ & \\
\hline
\end{tabular}

(1) Means followed by the same small letter(s), do not significantly different at 0.05 level of probability.

(2) Means followed by the same capital letter(s), within the same column, do not significantly different at 0.05 level of probability.

(3) Means followed by the same capital letter(s) (in parentheses), within the same row do not significantly different at 0.05 level of probability. 
J. Agric. Sci. Mansoura Univ., 33 ( ' r), December, 2008

Table (2): The average numbers of infested wheat plants $/ \mathrm{m}^{2}$ by rodents in relation to time and distances during the winter season of 2004 and 2005.

\begin{tabular}{|c|c|c|c|c|c|c|}
\hline \multirow{3}{*}{ Sampling date } & \multicolumn{5}{|c|}{ Average number of infested plants / $\mathrm{m}^{2}$ in 2004} & \multirow{3}{*}{$\begin{array}{l}\text { (2) Grand avg. } \\
\text { Sampling } \\
\text { date }\end{array}$} \\
\hline & \multicolumn{5}{|c|}{ Distance (m) } & \\
\hline & $1.0 \mathrm{~m}$ & $10.0 \mathrm{~m}$ & $20.0 \mathrm{~m}$ & $30.0 \mathrm{~m}$ & $40.0 \mathrm{~m}$ & \\
\hline Apr. 1 & (1) 3.0 def & 3.0 def & 1.8 ef & $1.6 \mathrm{f}$ & $1.4 \mathrm{f}$ & $2.16 \mathrm{D}$ \\
\hline 8 & 4.2 cdef & $3.6 \mathrm{cdef}$ & 2.4 def & 2.4 ef & 1.6 ef & $2.84 \mathrm{D}$ \\
\hline 15 & 6.2 cdef & 5.4 cdef & 3.6 cdef & 3.2 def & 1.8 ef & $4.04 \mathrm{CD}$ \\
\hline 22 & 10.8 abcdef & 6.8 cdef & 5.4 cdef & 5.6 cdef & $4.8 \mathrm{cdef}$ & $6.68 \mathrm{BC}$ \\
\hline 29 & $15.0 \mathrm{abc}$ & 9.6 bcdef & 8.6 bcdef & $8.2 \mathrm{cdef}$ & 5.4 cdef & $9.36 \mathrm{AB}$ \\
\hline May.6 & $22.8 \mathrm{ab}$ & 13.2 abcde & 11.4 abcdef & 10.0 cdef & $7.2 \mathrm{cdef}$ & $12.92 \mathrm{~A}$ \\
\hline 13 & $25.0 \mathrm{a}$ & $14.8 \mathrm{abcd}$ & 12.4 abcdef & 11.0 cdef & $6.0 \mathrm{cdef}$ & $13.84 \mathrm{~A}$ \\
\hline
\end{tabular}


Metwaly, A.M. et al

\begin{tabular}{|c|c|c|c|c|c|c|}
\hline 20 & $25.8 \mathrm{a}$ & $15.4 \mathrm{abcd}$ & 12.8 abcdef & 11.0 cdef & 6.4 cdef & $14.28 \mathrm{~A}$ \\
\hline $\begin{array}{l}\text { (3) Grand avg. } \\
\text { distance }\end{array}$ & $14.10(\mathrm{~A})$ & 8.98 (B) & $7.30(\mathrm{BC})$ & 6.63 (CD) & 4.33 (D) & \\
\hline \multicolumn{7}{|c|}{ Season 2005} \\
\hline Apr. 1 & (1) $3.0 \mathrm{~cd}$ & $2.4 \mathrm{~cd}$ & $1.8 \mathrm{~cd}$ & $1.2 \mathrm{~d}$ & $0.8 \mathrm{~d}$ & $1.84 \mathrm{D}$ \\
\hline 8 & $4.2 \mathrm{~b}-\mathrm{d}$ & $3.0 \mathrm{~cd}$ & $2.6 \mathrm{~cd}$ & $1.8 \mathrm{~cd}$ & $1.4 \mathrm{~cd}$ & $2.60 \mathrm{D}$ \\
\hline 15 & $6.0 \mathrm{a}-\mathrm{d}$ & $4.2 \mathrm{~cd}$ & $3.6 \mathrm{~cd}$ & $2.6 \mathrm{~cd}$ & $2.0 \mathrm{~cd}$ & $3.68 \mathrm{CD}$ \\
\hline 22 & $9.2 \mathrm{a}-\mathrm{d}$ & $6.0 \mathrm{~b}-\mathrm{d}$ & $5.0 \mathrm{~b}-\mathrm{d}$ & $3.8 \mathrm{~cd}$ & $3.0 \mathrm{~cd}$ & $5.40 \mathrm{BCD}$ \\
\hline 29 & $13.0 \mathrm{a}-\mathrm{c}$ & $7.6 \mathrm{a}-\mathrm{d}$ & $6.4 \mathrm{~b}-\mathrm{d}$ & $5.6 \mathrm{~b}-\mathrm{d}$ & $5.0 \mathrm{~b}-\mathrm{d}$ & $7.52 \mathrm{ABC}$ \\
\hline May.6 & $18.0 \mathrm{ab}$ & $10.2 \mathrm{a}-\mathrm{d}$ & 8.6 a-d & 8.0 a-d & 7.6 a-d & $10.48 \mathrm{AB}$ \\
\hline 13 & $20.4 \mathrm{a}$ & 11.0 a-d & 10.2 a-d & 9.2 a-d & 8.4 a-d & $11.84 \mathrm{~A}$ \\
\hline 20 & $20.8 a$ & $11.4 \mathrm{a}-\mathrm{d}$ & 10.2 a-d & 9.6 a-d & $8.8 \mathrm{a}-\mathrm{d}$ & $12.16 \mathrm{~A}$ \\
\hline $\begin{array}{l}\text { (3) Grand avg. } \\
\text { distance }\end{array}$ & $11.82(\mathrm{~A})$ & 6.98 (B) & $6.05(\mathrm{~B})$ & $5.23(\mathrm{~B})$ & $4.63(\mathrm{~B})$ & \\
\hline
\end{tabular}

(1) Means followed by the same small letter(s), do not significantly different at 0.05 level of probability.

(2) Means followed by the same capital letter(s), within the same column, do not significantly different at $\mathbf{0 . 0 5}$ level of probability.

(3) Means followed by the same capital letter(s) (in parentheses), within the same row do not significantly different at 0.05 level of probability. 
Table (3): The average percentage of infested maize ears $/ \mathrm{m}^{2}$ by rodents rodents in relation to time and distances during the winter season of 2004 and 2005.

\begin{tabular}{|c|c|c|c|c|c|c|}
\hline \multirow{3}{*}{ Sampling date } & \multicolumn{5}{|c|}{ Average number of infested ears / $\mathrm{m}^{2}$ in 2004} & \multirow{3}{*}{$\begin{array}{c}\text { Grand avg. } \\
\text { Sampling } \\
\text { date }\end{array}$} \\
\hline & \multicolumn{5}{|c|}{ Distance (m) } & \\
\hline & $1.0 \mathrm{~m}$ & $10.0 \mathrm{~m}$ & $20.0 \mathrm{~m}$ & $30.0 \mathrm{~m}$ & $40.0 \mathrm{~m}$ & \\
\hline Sep. 15 & 9.32 & 8.44 & 7.34 & 7.38 & 6.94 & 7.88 \\
\hline 22 & 9.78 & 8.44 & 8.24 & 7.86 & 6.94 & 8.25 \\
\hline 29 & 10.54 & 10.78 & 9.08 & 7.30 & 7.54 & 9.05 \\
\hline Oct. 6 & 11.18 & 11.44 & 9.40 & 7.11 & 8.00 & 9.43 \\
\hline 13 & 15.90 & 13.74 & 7.82 & 9.06 & 10.22 & 11.35 \\
\hline 20 & 15.58 & 12.96 & 9.96 & 11.08 & 10.86 & 12.09 \\
\hline Grand avg. distance & 12.05) & 10.97 & 8.64 & 8.30 & 8.42 & \\
\hline \multicolumn{7}{|c|}{ Season 2005} \\
\hline Sep.15 & 12.64 & 10.94 & 10.48 & 10.08 & 8.64 & 10.56 \\
\hline 22 & 19.72 & 12.84 & 11.40 & 10.54 & 9.62 & 12.82 \\
\hline 29 & 20.36 & 14.24 & 12.96 & 11.92 & 10.60 & 14.02 \\
\hline Oct.6 & 20.68 & 15.46 & 12.96 & 12.26 & 11.30 & 14.53 \\
\hline 13 & 22.96 & 19.16 & 15.30 & 13.82 & 12.46 & 16.74 \\
\hline 20 & 23.52 & 19.16 & 15.90 & 14.42 & 12.46 & 17.09 \\
\hline Grand avg. distance & 19.98 & 15.30 & 13.17 & 12.17 & 10.85 & \\
\hline
\end{tabular}

\section{Sorghum (Sorghum vulgar):}

The percentage of infested sorghum panicle by rodents at different dates and distances during 2004 and 2005 seasons are shown in Table (4). The rodents attacked the sorghum plants once the panicle appearance to the harvesting. The period from $29^{\text {th }}$ September to $7^{\text {th }}$ October in both seasons was the most preferred period. There was difference between the last examination date and the first examination date in both seasons. There results were true in both seasons varying distances from field borders caused affect on damage of sorghum by rodents. It was found that the high damage was clear in the plants near the field borders. The damage was about (8.05 and 11.80) during 2004 and 2005, respectively. By increasing the distances, the damage was gradually tended to be reduce. The minimum rate of damage was $5.30,4.76$ and 4.45 at 20,30 and $40 \mathrm{~m}$, respectively in season 2004, and it was 7.80, 7.16 and 6.36 in season 2005 for the corresponding distances. 
Metwaly, A.M. et al

Table (4): The average percentage of infested sorghum panicle $/ \mathrm{m}^{2}$ by rodents in relation to time and distances during the winter season of 2004 and 2005.

\begin{tabular}{|c|c|c|c|c|c|c|}
\hline \multirow{3}{*}{$\begin{array}{l}\text { Sampling } \\
\text { date }\end{array}$} & \multirow{2}{*}{\multicolumn{5}{|c|}{$\begin{array}{c}\text { Average number of infested panicle } / \mathrm{m}^{2} \text { in } 2004 \\
\text { Distance }(\mathrm{m})\end{array}$}} & \multirow{3}{*}{$\begin{array}{c}\text { Grand avg. } \\
\text { Sampling } \\
\text { date }\end{array}$} \\
\hline & & & & & & \\
\hline & $1.0 \mathrm{~m}$ & $10.0 \mathrm{~m}$ & $20.0 \mathrm{~m}$ & $30.0 \mathrm{~m}$ & $40.0 \mathrm{~m}$ & \\
\hline Sep. 15 & 5.82 & 4.58 & 5.10 & 3.88 & 3.90 & 4.66 \\
\hline 22 & 6.54 & 5.92 & 4.42 & 4.64 & 4.28 & 5.16 \\
\hline 29 & 8.00 & 7.18 & 4.80 & 4.46 & 4.00 & 5.69 \\
\hline Oct. 6 & 9.82 & 7.22 & 5.46 & 4.48 & 4.64 & 6.32 \\
\hline 13 & 9.44 & 8.12 & 5.96 & 5.42 & 4.66 & 6.72 \\
\hline 20 & 8.66 & 8.34 & 6.06 & 5.66 & 5.22 & 6.79 \\
\hline $\begin{array}{l}\text { Grand avg. } \\
\text { distance }\end{array}$ & 8.05 & 6.89 & 5.30 & 4.76 & 4.45 & \\
\hline \multicolumn{7}{|c|}{ Season 2005} \\
\hline Sep. 16 & 9.32 & 6.32 & 5.64 & 5.44 & 4.68 & 6.28 \\
\hline 23 & 9.70 & 6.60 & 5.88 & 5.44 & 4.68 & 6.46 \\
\hline 30 & 10.60 bcdefgh & 8.64 & 7.04 & 6.54 & 6.06 & 7.78 \\
\hline Oct. 7 & 12.18 & 9.86 & 8.12 & 7.56 & 6.92 & 9.83 \\
\hline 14 & 13.72 & 11.12 & 9.52 & 9.00 & 7.92 & 10.26 \\
\hline 21 & 15.28 & 12.78 & 10.58 & 9.00 & 7.92 & 11.11 \\
\hline $\begin{array}{l}\text { Grand avg. } \\
\text { distance }\end{array}$ & 11.80 & 9.22 & 7.80 & 7.16 & 6.36 & \\
\hline
\end{tabular}


It can be concluded that the field rodents attacked the broad bean, wheat, maize and sorghum crops in various growth stages. The percentage of damage reached to its maximum during the periods of $12-26^{\text {th }}$ February for broad bean and during the period from $22^{\text {nd }}$ April to $6^{\text {th }}$ May for wheat. Also, The percentage of damage reached to its maximum during the periods from 13 to $20^{\text {th }}$ October for maize and during the period from $30^{\text {th }}$ September to $7^{\text {th }}$ October for sorghum crop. The infestation was high in all the studied crops within the first ten meters from the field borders and gradually decreased towards the middle of the field. This may be attributed to the concentration of the burrows of rodents which prefer the field near irrigation canals. These results confirmed the good relationship between stage of crops maturity and extent of rodent infestation. Abdel-Gawad et al., (1982) found that the increase of the burrows is naturally accompanied with the increase of rodent population and the damage caused by rodents in some field crops (wheat, sorghum, maize and cotton) to be concentrated on the borders of the cultivated areas and decreased towards the field center.

\section{REFERENCES}

Abazaid, A.A. (1997): Ecological and toxicological studies on rodents in Qena governorate (Upper Egypt). Ph. D. Thesis, Fac. Agric., Assiut Univ., pp. 96.

Abdel-Hamid, E.A. (1997): Some ecological and toxicological studies on certain Egyptian rodents. Ph. D. Thesis, Fac. Agric., Al-Azhar Univ., Egypt.

Abdel-Gawad, K.H.; Farghal, A.I.; El-Eraky, S.A. and Abazaid, A.A. (2000): Damage caused by rodents to some field crops and date- palm. The $2^{\text {nd }}$ Sci. Conf. of Agric. Sci., Assiut, October.

Abdel-Gawad, K.H.; Maher Ali, A. and Salit, A.M. (1982): Assessment of damage caused by rodents in some field crops. Assiut J. Agric. Sci., 13(2): 73-78.

Ahmed, M.Y.M. (2001): Studies on the field rat. M. Sc. Thesis, Fac. Agric., Al-Azhar Univ., pp.144.

Asran, A.A. (1991): Chrronology of damage appraised in some field crops caused by the Nile rat, Arvicanthis . niloticus in Minia Governorate. $4^{\text {th }}$ Arab congress of plant protection Cairo, 1-5 Dec., Vol. II. pp. 509-513.

Asran, A.A.; El-Deeb, H.I. and El-Halfawy, M.A. (1990): Field trails on certain anticoagulant rodenticides against the field rat Arvicanthis niloticus. Egypt. J. Res., 70(2): 461-467.

El-Nashar, M.A. (1998): Ecological and toxicological studies on some Egyptian rodents in certain traditional cultivated areas in some governorates in Egypt.M. Sc.Thesis, Fac.Agric., Al-Azhar Univ., pp. 62.

Embarak, M.Z. (1997): Ecological and control studies on rodents and their ectoparasites in cultivated and newly-reclaimed areas. M. Sc. Thesis, Fac. Agric., Assiut Univ. 130 pp. 


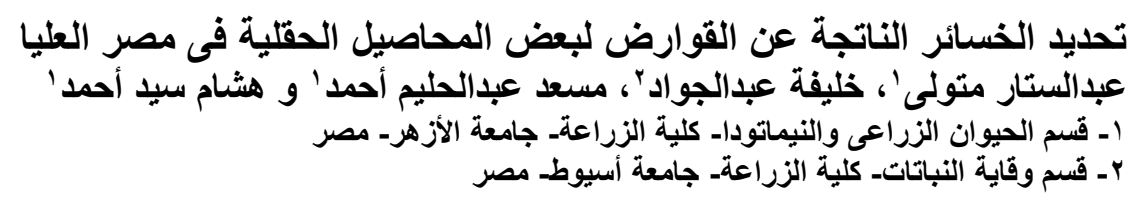

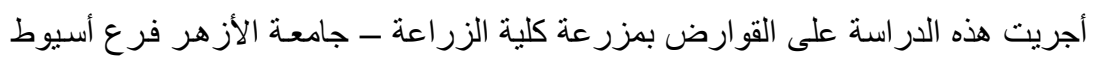

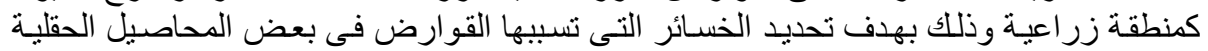

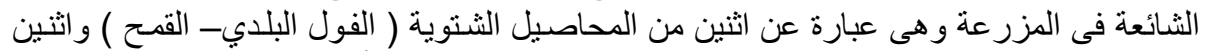

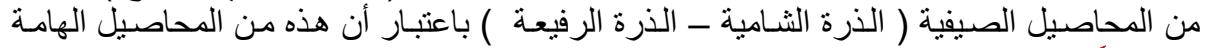
اقتصادياً فى مر احل النمو المختلفة.

وجد أن الإصابة بالقو ارض فى الفول البل البلدى والقمح و الذرة الثـامية والذرة الرفيعة تتركز

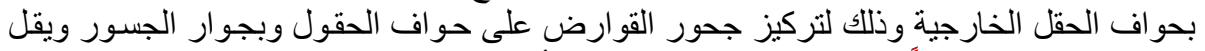

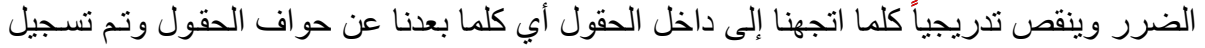

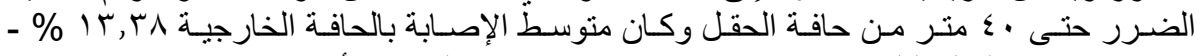

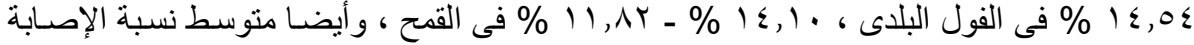

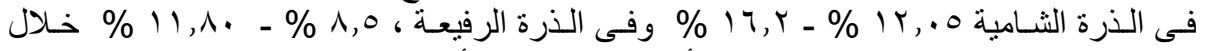

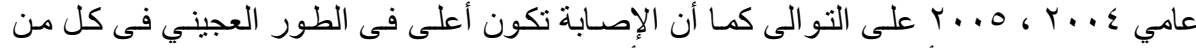
الفول البلاى و القمح ـ أما الذرة فتكون الإصابة أعلى فى طور ما قبل الحصاد الطياد. 